\title{
Two-dimensional Gel Electrophoretic Separation of the Proteins Present in Chromatin of Escherichia coli
}

\author{
By IVAR LOSSIUS, * KNUT SJÅSTAD, LARS HAARR AND \\ K JELL KLEPPE \\ Department of Biochemistry, University of Bergen, Arstadvein 19, Bergen, Norway
}

(Received 17 April 1984; revised 13 July 1984)

The polypeptides present in ${ }^{35} \mathrm{~S}$-labelled chromatin prepared from Escherichia coli cells, and
polypeptides present in the DNA and RNA complexes obtained by micrococcal nuclease diges-
tion of the chromatin, were analysed by two-dimensional non-equilibrium polyacrylamide gel
electrophoresis. Three hundred and thirty-five ${ }^{35}$ S-labelled polypeptides were detected in the
chromatin whereas the DNA-and RNA-containing fractions of the micrococcal nuclease digest
contained 126 and 183 polypeptides respectively. The major basic low-molecular-weight poly-
peptides were found in the DNA-containing fractions.

\section{INTRODUCTION}

In a previous study, chromatin from Escherichia coli was isolated by a new method and subsequently characterized (Sjåstad et al., 1982). Briefly, the $E$. coli cells were lysed by treatment with T4 lysozyme followed by freezing and thawing once. The lysate was incubated on ice with a solution containing the non-ionic detergent Nonidet P-40 and the insoluble fraction was collected by centrifugation. The washing with the detergent solution was repeated three times and the resulting viscous material was termed bacterial chromatin. The chromatin contained DNA and RNA in a ratio of approximately $1: 1$ and the amount of protein present was approximately three times that of the nucleic acids. The proteins characterized by one-dimensional gel electrophoresis consisted of a number of high- and low-molecular-weight components.

In the present report we describe the analysis by two-dimensional gel electrophoresis of the polypeptides of protein present in chromatin and in the DNA- and RNA-containing fractions separated by sucrose gradient centrifugation of micrococcal nuclease digested chromatin.

\section{METHODS}

Chromatin from E. coli K12 DG75- thy leu was prepared essentially as described previously (Sjåstad et al., 1982). The polypeptides were labelled by adding ${ }^{35} \mathrm{SO}_{4}^{2-}$ to the $\mathrm{M} 9$ medium. One-dimensional gel electrophoresis was carried out according to the method of Laemmli \& Favre (1973) and two-dimensional gel electrophoresis as previously described (O'Farrell, 1975; O'Farrell et al., 1977; Sjåstad et al., 1982). Ribosomes were prepared as described by Kaji (1968). Outer and inner membranes of $E$. coli were prepared by the method of Sato et al. (1977).

For ease of comparison of the different gels, the polypeptides have been given reference numbers based on coordinates as indicated in Fig. 1. The position of polypeptides in the basic, low-molecular-weight region (abscissa $<50$, ordinate $<50$ ) was largely dependent on the duration of electrophoresis. The coordinates assigned to polypeptides in this region were derived from the electrophoresis of samples of cytoplasmic proteins from $E$. coli which bound to a DNA-cellulose column and were eluted by a salt gradient (Sjåstad et al.. 1983).

\section{RESULTS AND DISCUSSION}

The two-dimensional gel electrophoretic patterns of the polypeptides present in total chromatin, and in the 24S RNA fraction and the 10S DNA fraction obtained after sucrose gradient separation of the micrococcal nuclease digested chromatin, are shown in Figs 1, 2 and 3 


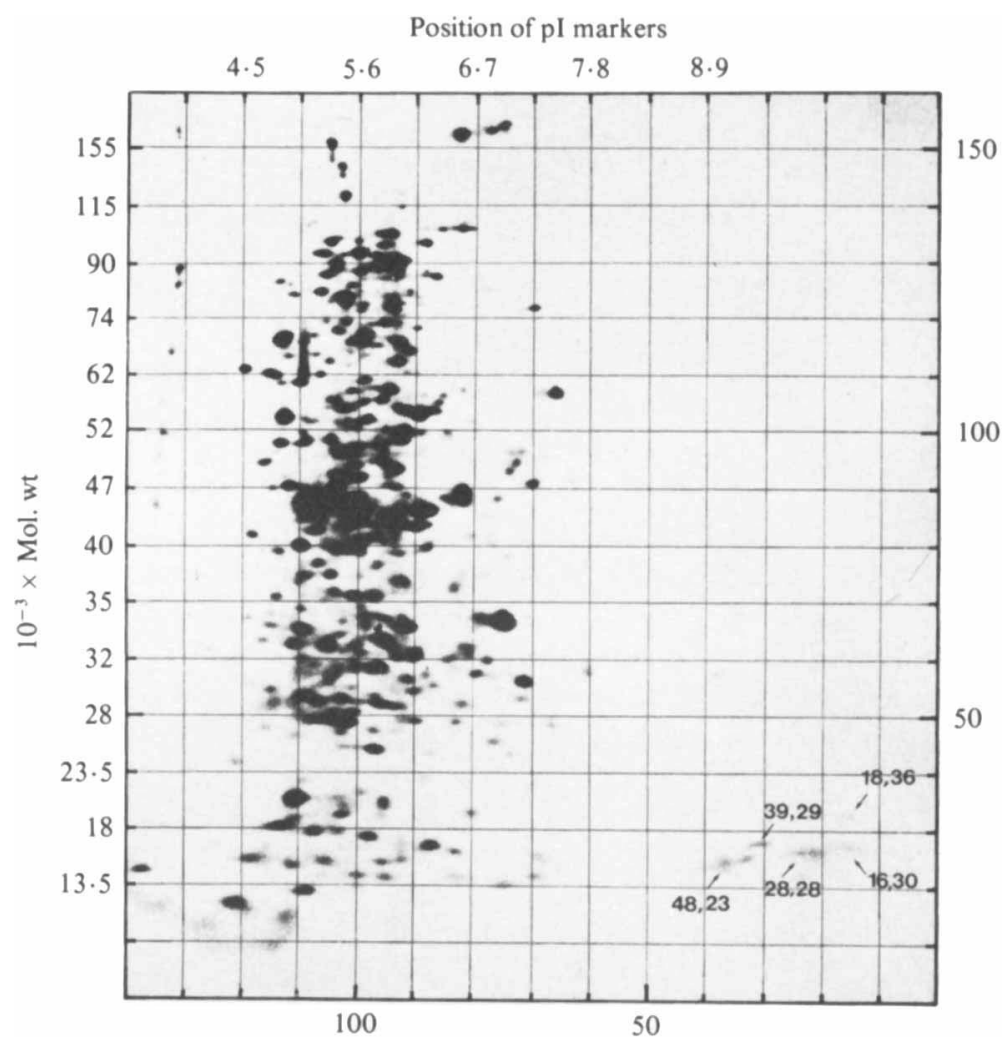

Fig. 1. Fluorograph of the two-dimensional electrophoretic separation of ${ }^{35} \mathrm{~S}-$ labelled proteins present in total chromatin of $E$. coli K12. The pI markers used were the same as described by Sjåstad et al. (1983).

respectively. The total numbers of labelled polypeptides detected in these samples were 335 (Fig. 1), 126 (Fig. 2) and 183 (Fig. 3). The polypeptide patterns of the DNA- and RNA-containing fractions were different. Several polypeptides co-sedimented with both DNA and RNA, suggesting that some of the proteins may form complexes with both kinds of nucleic acid or, alternatively, that some RNA was present in the DNA fraction and vice versa. The major polypeptides associated exclusively with the 24S RNA are indicated by coordinate numbers in Fig. 2 and their molecular weights and charge characteristics are shown in Table 1.

The majority of the low-molecular-weight basic polypeptides co-sedimented with the DNA peak whereas the acidic low-molecular-weight polypeptides were found either in the top fractions of the sucrose gradient or in the $30 \mathrm{~S}$ to $40 \mathrm{~S}$ fractions, which also contained fragments of spheroplast envelopes (results not shown). The results suggested that the low-molecular-weight basic proteins were bound to the DNA, whereas the presence of acidic low-molecular-weight polypeptides was due to solubilized or unremoved membrane fragments.

The polypeptide patterns shown in Figs 1, 2 and 3 were compared with the pattern obtained after electrophoresis of the total cytoplasmic DNA-binding proteins of $E$. coli (Sjåstad et al., 1983). Only the major polypeptides were analysed in this way. A total of 26 of the major polypeptides shown in Fig. 3 had identical mobilities to polypeptides present in the different salt eluates of the DNA-cellulose column. These are indicated by their coordinate numbers in Fig. 3 and their identities are presented in Table 2 . Four of these polypeptides $(39,29 ; 94,130 ; 100,132$; $112,113)$ were also present as major polypeptides in the outer membrane fractions prepared according to Sato et al. (1977) whereas two $(30,37$ and 112,113$)$ were present in ribosome preparations. The polypeptides 69,22 and 69,25 , not detected among the total cytoplasmic DNA- 


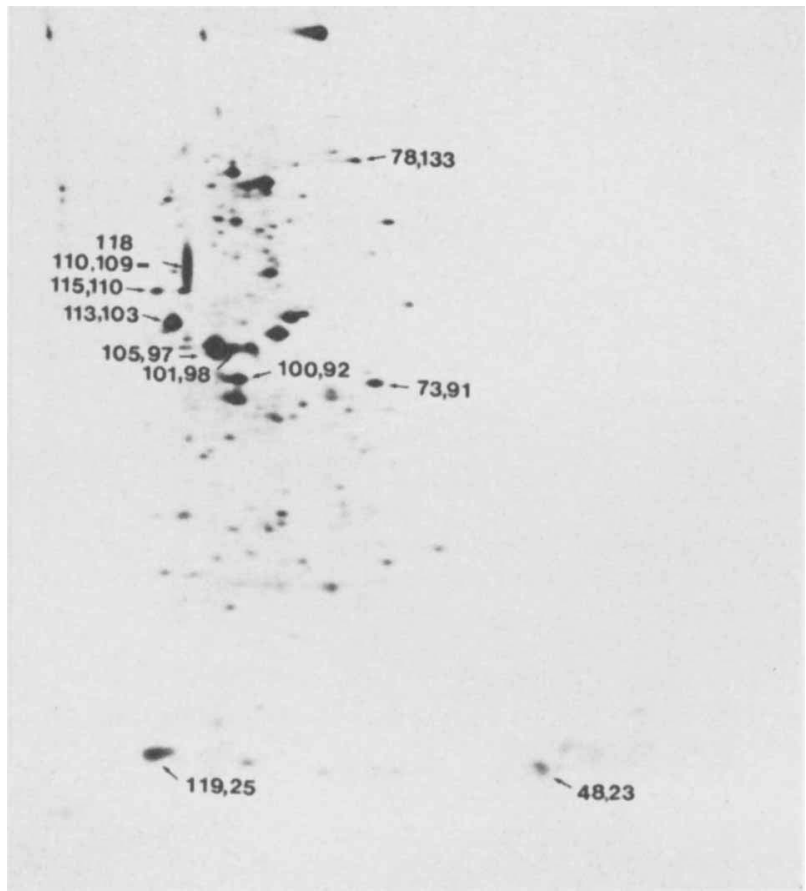

Fig. 2. Fluorograph of the two-dimensional electrophoretic separation of ${ }^{35} \mathrm{~S}$-labelled proteins present in the 24S RNA fraction isolated from $E$. coli $\mathrm{K} 12$ chromatin after nuclease digestion and sucrose gradient centrifugation.

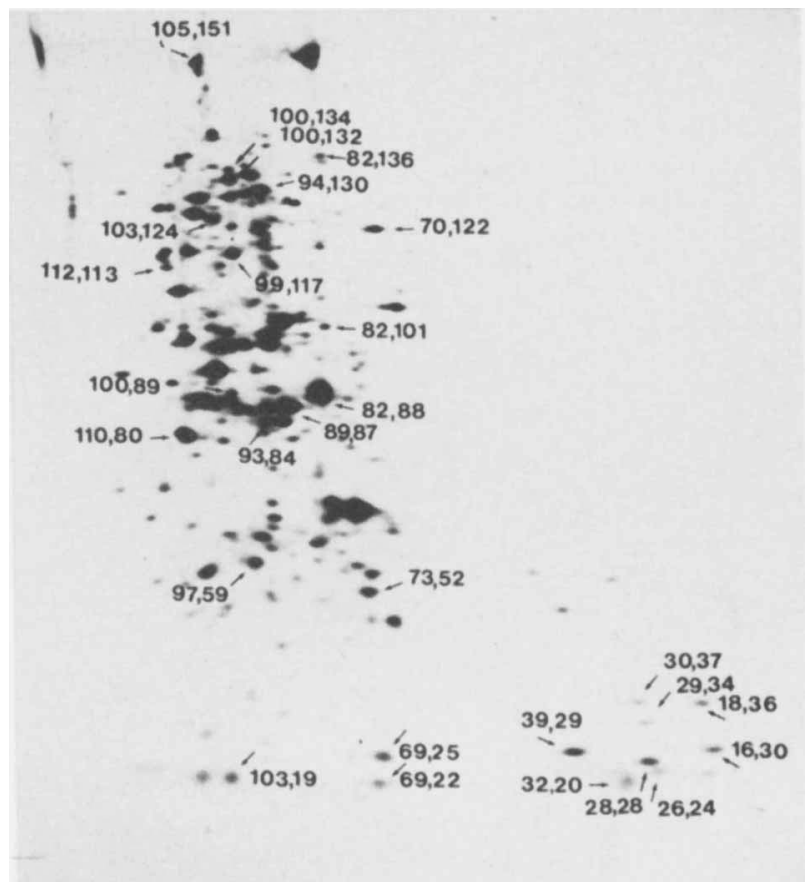

Fig. 3. Fluorograph of the two-dimensional electrophoretic separation of ${ }^{35} \mathrm{~S}$-labelled proteins in the IOS DNA fraction isolated from $E$. coli $\mathrm{K} 12$ chromatin after nuclease digestion and sucrose gradient centrifugation. 
Table 1. Major polypeptides co-sedimenting exclusively with the $24 S$ RNA fraction isolated from $E$. coli K12 chromatin after nuclease digestion and sucrose gradient centrifugation

$\begin{array}{lcc}\begin{array}{c}\text { Polypeptide } \\ \text { coordinates* }\end{array} & \begin{array}{c}10^{-3} \times \\ \text { Mol. wt }\end{array} & \begin{array}{c}\text { Migration } \\ \text { relative to } \\ \text { pI markers }\end{array} \\ 48,23 & 15 & 8 \cdot 5 \\ 73,91 & 47 & 7 \cdot 2 \\ 78,133 & 98 & 6 \cdot 8 \\ 100,92 & 47 & 5 \cdot 6 \\ 105,97 & 50 & 5 \cdot 3 \\ 110,109-118 & 60-70 & 5 \cdot 0 \\ 113,103 & 55 & 4 \cdot 9 \\ 115,110 & 62 & 4 \cdot 8 \\ 119,25 & 16 & 4 \cdot 5\end{array}$

* Coordinates are the abscissa and ordinate values (in arbitrary units) shown in Fig. 1.

† Estimated pI of peptide derived by comparison of migration with that of peptides of known pI.

Table 2. Identification of major polypeptides present both in the 10S DNA fraction and among the cytoplasmic DNA-cellulose binding proteins of E. coli K12

\begin{tabular}{|c|c|c|c|c|}
\hline \multirow{2}{*}{$\begin{array}{c}\text { 10S DNA } \\
\text { coordinates* }\end{array}$} & \multicolumn{2}{|c|}{$\begin{array}{l}\text { Cytoplasmic DNA-cellulose } \\
\text { binding polypeptides } \dagger\end{array}$} & \multirow{2}{*}{$\begin{array}{l}10^{-3} \times \\
\text { Mol.wt }\end{array}$} & \multirow{2}{*}{$\begin{array}{l}\text { Migration } \\
\text { relative to } \\
\text { pI markers }\end{array}$} \\
\hline & No. & $\mathrm{NaCl}$ concn & & \\
\hline 16,30 & 160 & 0.4 & 18 & $10 \cdot 5$ \\
\hline 18,36 & 148 & 0.4 & 21 & $10 \cdot 1$ \\
\hline 26,24 & 77 & $0 \cdot 15-0 \cdot 6$ & 16 & 9.7 \\
\hline 28,28 & 73 & $0 \cdot 15-0.6$ & 17 & $9 \cdot 6$ \\
\hline 29,34 & 202 & $0.6-2 \cdot 0$ & 20 & $9 \cdot 6$ \\
\hline 30,37 & 145 & $0 \cdot 4-2 \cdot 0$ & 22 & $9 \cdot 5$ \\
\hline 32,20 & - & $0 \cdot 15$ & 14 & $9 \cdot 3$ \\
\hline 39,29 & 159 & 0.4 & 18 & 8.9 \\
\hline 70,122 & 86 & 0.4 & 77 & $7 \cdot 2$ \\
\hline 73,52 & 188 & $0 \cdot 4-2 \cdot 0$ & 29 & $7 \cdot 1$ \\
\hline 82,88 & 20 & $0 \cdot 15$ & 44 & $6 \cdot 6$ \\
\hline 82,101 & 11 & $0.15-0.4$ & 53 & $6 \cdot 6$ \\
\hline 82,136 & 170 & $0 \cdot 6-2 \cdot 0$ & 105 & $6 \cdot 6$ \\
\hline 89,87 & 179 & $0 \cdot 6-2 \cdot 0$ & 43 & $6 \cdot 2$ \\
\hline 93,84 & 23 & $0 \cdot 15$ & 42 & 5.9 \\
\hline 94,130 & 4 & $0.15-0.4$ & 92 & 5.8 \\
\hline 97,59 & 122 & 0.4 & 32 & $5 \cdot 7$ \\
\hline 99,117 & 88 & $0 \cdot 15-0.4$ & 70 & $5 \cdot 6$ \\
\hline 100,89 & 177 & $0 \cdot 6-2 \cdot 0$ & 45 & $5 \cdot 6$ \\
\hline 100,132 & 169 & $0.4-0.6$ & 95 & $5 \cdot 6$ \\
\hline 100,134 & 2 & $0 \cdot 15-2 \cdot 0$ & 100 & 5.6 \\
\hline 103,19 & 79 & $0 \cdot 15-2 \cdot 0$ & 13 & $5 \cdot 3$ \\
\hline 103,124 & 5 & $0.15-0.6$ & 80 & $5 \cdot 3$ \\
\hline 105,151 & $166 / 67$ & $0.4-2.0$ & 160 & $5 \cdot 2$ \\
\hline 110,80 & $180 / 181$ & $0 \cdot 15-2 \cdot 0$ & 40 & $5 \cdot 0$ \\
\hline 112,113 & 95 & $0 \cdot 15-2 \cdot 0$ & 65 & 4.9 \\
\hline
\end{tabular}

* Coordinates are the abscissa and ordinate values (in arbitrary units) shown in Fig. 1.

$\dagger$ Figures are the polypeptide number and the $\mathrm{NaCl}$ concentration (M) at which eluted from DNA-cellulose column (Sjåstad et al, 1983).

$\ddagger$ Estimated pI of peptide derived by comparison of migration with that of peptides of known pl.

cellulose binding proteins, did bind to double-stranded DNA-Sepharose. The 69,22 polypeptide also bound to single-stranded DNA-Sepharose (A. Holck, unpublished observation).

The results suggested that protein species in the chromatin can be divided into several classes, those specifically associated with RNA, those bound to DNA, and a group of proteins only 
loosely associated with the chromatin and found at the top of the sucrose gradient after sedimentation of the micrococcal nuclease digested chromatin. Also, there may be a class of proteins which can bind equally well to both RNA and DNA.

Less than half of the major proteins co-sedimenting with the 10S DNA were found among the cytoplasmic proteins known to bind to DNA-cellulose. The reason for this is probably related to the way the protein samples were prepared. For preparation of cytoplasmic proteins, the cells were disrupted by sonication and cell walls and membranes sedimented by high-speed centrifugation prior to nuclease digestion of the supernatant solution (Sjåstad et al., 1983). For preparation of chromatin, the membranes were lysed by the non-ionic detergent Nonidet P- 40 . In this process DNA-binding proteins present in the membrane may have been solubilized and then become associated with chromatin. It is therefore suggested that some of the high-molecular-weight proteins of the $10 \mathrm{~S}$ fraction may be membrane proteins. Recently a number of membrane proteins have been shown to have affinity for DNA (Jacq \& Kohiyama, 1980; Kohiyama et al., 1977; Hendrickson et al., 1982; Nicolaidis \& Holland, 1978; Portalier \& Worcel, 1976; Wolf-Watz \& Norqvist, 1979).

An alternative explanation for the differences in polypeptide patterns may be the occurrence of post-translational modification (phosphorylation, acetylation, etc.) of protein, causing the forms predominantly present in the cytoplasm to differ from those which are bound to the DNA.

Studies are now in progress to determine which of the polypeptides can be considered to be true DNA-binding proteins.

This study was supported in parts by grants from the Norwegian Research Council for Science and Humanities and the Norwegian Cancer Society (HFKB).

We are grateful to Drs A. Holck and R. Aasland for many helpful discussions.

\section{REFERENCES}

Hendrickson, G. W., Kusano, T., Yamaki, H., Balakrishnan, R., King, M., Murchie, J. \& SCHAECTER, M. (1982). Binding of the origin of replication of Escherichia coli to the outer membrane. Cell 30, 915-923.

JACQ, A. \& KohIYAma, M. (1980). A DNA-binding protein specific for the early replicated region of the chromosome obtained from Escherichia coli membrane fractions. European Journal of Biochemistry 105, 25-31.

KAJI, A. (1968). Techniques for measuring specific sRNA binding to Escherichia coli ribosomes. Methods in Enzymology 12, 692-693.

Kohiyama, M., Kollek, R., Goebel, W. \& KePes, A. (1977). Escherichia coli proteins with an affinity for deoxyribonucleic acid. Journal of Bacteriology 129, 658-667.

LAEMmLI, U. K. \& FAVRe, M. (1973). Maturation of the head of bacteriophage T4. Journal of Molecular Biology 80, 575-599.

Nicolaidis, A. \& Holland, I. B. (1978). Evidence for the specific association of the chromosomal origin with outer membrane fractions isolated from Escherichia coli. Journal of Bacteriology 135, 178-189.

O'FARRELL, P. H. (1975). High resolution two-dimensional electrophoresis of proteins. Journal of Biological Chemistry 250, 4007-4021.
O'Farrell, P., Goodman, M. H. \& O'Farrell, P. H. (1977). High resolution two-dimensional electrophoresis of basic as well as acidic proteins. Cell 12, 1133-1142.

Portalier, R. \& Worcel, A. (1976). Association of the folded chromosome of Escherichia coli: characterization of the proteins at the DNAmembrane attachment site. Cell 8, 245-255.

Sato, T., Ito, K. \& YuRA, T. (1977). Membrane proteins of Escherichia coli K-12: two-dimensional polyacrylamide gel electrophoresis of inner and outer membranes. European Journal of Biochemistry 78, 557-567.

SiÅstad, K., FADNes, P., KRuger, P. G., Lossius, I. \& KLEPPE, K. (1982). Isolation, properties and nucleolytic degradation of chromatin from Escherichia coli. Journal of General Microbiology 128, 3037-3050.

SJÅStad, K., HAARR, L. \& KlePPE, K. (1983). Characterization of the DNA-cellulose binding proteins from Escherichia coli K-12. Biochimica et biophysica acta 739, 8-16.

Wolf-Watz, H. \& Norqvist, A. (1979). Deoxyribonucleic acid and outer membrane: binding to the outer membrane involves a specific protein. Journal of Bacteriology 140, 43-49. 